Journal of Development and Communication Studies

Vol. 5. No. 1, July 2016 - June 2017 ISSN (Online E Print): 2305-7432.

http://www.devcomsjournalmw.org.

\title{
Assessment of factors affecting social media use for HIV andAIDS communication among undergraduate students in South-Western Nigeria
}

Ayodele John Alonge, CARTA PhD Fellow, School of Journalism and Mass Communication, University of Nairobi, Kenya; ayoalonge@gmail.com,

Wambui Kiai, Senior Lecturer, School of Journalism and Mass Communication, University of Nairobi, Kenya, wamkiai@yahoo.com $\mathcal{E}$

Ndeti Ndati, Senior Lecturer \& Director, School of Journalism and Mass Communication, University of Nairobi, Kenya, ndanundeti@gmail.com

\begin{abstract}
The study evaluated factors that affect use of social media for HIV and AIDS communication among federal university undergraduates in south western Nigeria. The cross-sectional research method was employed. Structured questionnaire copies were administered to 355 undergraduate students. Quantitative data gathered from the administered questionnaire were analyzed using descriptive and inferential statistics. Result showed that blogs (41.1\%), twitter (25.4\%) and WhatsApp $(17.7 \%)$ were the social media sites preferred by male and female respondents for sharing and accessing HIV and AIDS information. The use of these social media sites for HIV and AIDS information communication was influenced by privacy and neutrality. It also showed that majority of the undergraduates affirmed that HIV and AIDS information on social media platforms was very useful because it facilitated access to quality tips on HIV. A significant percentage of the respondents also affirmed that the use of social media was hugely affected by epileptic nature of power supply, poor network connectivity, ICT skills and cost of subscription. Stepwise multiple regression analysis identified ICT skill as the only environmental factor that had significant influence on social media use $(F=4.234, p<0.05)$ and was responsible for $33.9 \%$ of the variation in social media use for HIV information communication. The study suggested the campaign on prominent HIV/AIDS discussion sites and ICT skill acquisition to enable youth connect and effectively make use of social media for HIV information communication.
\end{abstract}

Key words: Social media, HIV/AIDS information, communication, barriers

To cite this article: Alonge, A.J., Kiai, W. \& Ndati, N. (2017). Assessment of factors affecting social media use for HIV and AIDS communication among undergraduate students in South-Western Nigeria. Journal of Development and Communication Studies, 5(1): 56-77. https://dx.doi.org/10.4314/jdcs.v5i1.4 


\section{Introduction}

HIV is global health challenge whose cure has not yet been found. The deadly virus has infected many youths world over. However, a greater percentage of the youths infected HIV in the world is found in Sub-Saharan Africa. UNICEF (2010) estimated that at the end of 2009, about 2.7 million youths were infected by the epidemic. The increasing number of youths with the deadly virus implies the need for increased HIV/AIDS information communication to reduce the growth of new infections in the sub-region (Mpofu and Salawu, 2014). Several efforts have been employed by health workers to create awareness on the mode of transmission and prevention of the epidemic, but these efforts seem not to have significant impacts due to cases of new infections. One way however, to reduce the rate of new infection and spread of the deadly virus by creating awareness is through the use of social media sites or platforms. Social media with a social focus is a platform that enables information to be shared through the process of networking (HRSA Care, 2011).

There are different social media sites; some of them include Facebook, YouTube, Instagram, Twitter, WhatsApp and MySpace among numerous others (Hughes et al., 2012; Taggart et al., 2015). These networking sites are used for diverse purposes like for chatting, updating profiles, connecting or making new friend, uploading pictures and sending of messages. The advent of this new media has solved the geographic problem of distance that usually impact on communication. This is because users can connect with one another for hours irrespective of their distance (Kaplan and Haenlein, 2010; Hughes et al., 2012). As a result of its acceptance and high utilization by youths, social media is becoming a suitable platform and channel or pathway for health information communication (Mpofu and Salawu, 2014). The use of these platforms for health information purposes is on currently on the rise with several acknowledging these networking sites as one of the most broadly used resource for health awareness campaign (Elkin, 2008; Fox and Jones, 2009).

Indeed, the existence of social networking platform makes it possible for people to connect with others, exchange health-related information and share experiences of better ways of managing health problems. One benefit of social media in HIV and AIDS information communication is its ability to offer a neutral platform for engagement people living with the virus to connect and share information on HIV prevention and treatment initiatives (Blackstock et al., 2015). This process helps to resolve the issues of stigma and cultural factors that hinder free sharing of HIV related information vis-à-vis discussion. Through this platform, individuals can seek and share information about specific prevention strategies (Taggart et al., 2015) and engage in dialogue about HIV research (Desouza and Jyoti, 2008), and leverage support for issues 
such as medication adherence and emotional coping for living with HIV (Horvath et al., 2013). In many Nigerian institutions, there are HIV and AIDS discussion forum which helps to create awareness about the deadly virus. This forum drums support for the control of new infections and need for safe sex among others. As a way to reach its members, online platform is usually created to easy communication and sharing of vital health information.

However, the use social media mostly in Sub-Sahara Africa and Nigeria in particular is affected by several factors such as epileptic and unstable power supply, frequent network connectivity problem, inadequate ICT skills and cost of subscription as well as cost of technological devices (Smartphone) and accessories (Idowu et al., 2004; Omotosho et al., 2015). These factors have tremendous impact on youths' use of social media and their ability to connect to online peer-to-peer social support group. In Africa and the world in general, the greater percentage of social media users are youths and many are in high schools (Madden et al., 2013; Ephraim, 2013; Mingle and Adams, 2015; Markwei and Appiah, 2016). As such, the cost of subscription has serious setbacks on youths' ability access social media sites and connects with people with similar health problems. This and many other factors affect the use of social media sites or platforms for HIV information communication. For instance, youths cannot connect with friends and loved ones to share problems and exchange health-related information when electricity is unstable. The devices (Smartphone) that enable people to remain connected with others can only function when they are charged and when the battery goes down, it needs to be powered to enable users always be online. This is the case in a situation where electricity supply is erratic.

Since the emergence of social media, there has been burgeoning literature on its use in HIV and AIDS communication (Sanghee and Soojung, 2014; Taggart et al., 2015). Several studies on this regards have been carried out on the usefulness this new media in advancing health campaign. Several studies have been carried out on the use of social media on HIV and AIDS prevention and intervention (Desouza and Jyoti, 2008; Horvath et al., 2013; Blackstock et al., 2015; Taggart et al., 2015). Studies have also been carried out to assess use of social media for health purpose by college students (Sanghee and Soojung, 2014). The study showed that American students engage more in social media interaction for health care experts, while Korean students built online bond with other people with similar health problems. In Nigeria, studies have also been carried out on social media. A good number of these studies only examined social media use and addiction by students in higher schools (Olowu and Fasola, 2012; Idubor, 2015). Some of the available studies on factors that affect the use of social media limited their search to ease of use, enjoyment, and perceived usefulness (Sago, 2013) neglecting fundamental problems such as power supply, internet 
connectivity, ICT skills and subscription cost. The present study however examines factors affecting social media use for HIV and AIDS communication among undergraduate students in south western Nigeria. Specifically, the study would examine the effect of power supply, internet connectivity, ICT skills and subscription cost on social media use. The specific objectives of the study were to:

1. Examine the usefulness of social media in HIV and AIDS information communication.

2. Determine undergraduate students' awareness of social media.

3. Find out the types of HIV and AIDS information shared on social media.

4. Find out the social media sites used by undergraduate students' for HIV and AIDS communication.

5. Determine the influence of power supply, internet connectivity, ICT skills and subscription cost on social media use.

\section{Materials and methods}

\section{Research Design, population of study and sampling technique}

The cross-sectional research method was employed. The study collected and analysed quantitative data using a structured questionnaire. The study population comprised undergraduate students in federal universities in southwest Nigeria. The multi-stage sampling technique was employed involving three stages. In the first stage, using purposive sampling technique was used to select Obafemi Awolowo University (OAU), University of Lagos (Unilag) and University of Ibadan (UI) based on their familiarity in the southwestern region. In the second stage, all undergraduate students were selected using stratified sampling technique. This technique was applied to sample students across different levels of study. The stratified sampling technique was also applied because the target population was enrolled in various major disciplines such as humanities, education social sciences, sciences, law, medicine, technology and management. In the fourth stage, systematic sampling method was employed to administer the structure questionnaire to students across the three universities. In order to ascertain the exact number of students to sample or administer questionnaire, the total population of undergraduates in Obafemi Awolowo University (OAU), University of Lagos (Unilag) and University of Ibadan (UI) were obtained from the Admission Office in the three universities. Fisher et al. (1983) formula was used to determine the sample size. Similar formula was employed by Mugenda and Mugenda (2003) and Ndeti (2013) as follows:

$$
\mathrm{n}=\frac{\mathrm{z}^{\mathrm{n}} \mathrm{pg}}{\mathrm{dx}^{\mathrm{n}}}
$$

Where $\mathrm{n}=$ the required sample size, when the target population is more than 10,000 
$\mathrm{Z}=$ is standard normal deviate at the required confidence level (1.96) at 0.05

$\mathrm{p}=$ is the proportion of the target population estimated to have the characteristics being measured when one is not sure, so one takes middle ground (0.5)

$$
\begin{aligned}
& q=1-p \\
& d=\text { is the level of statistical significance }
\end{aligned}
$$

Therefore $\mathrm{n}=\frac{1.96^{\mathrm{m}} \mathrm{n0.8 \times 0.5}}{0.06^{\mathrm{N}}}=384$

The calculation indicated that 384 undergraduates would be sampled. Hence, the distribution of questionnaire was done in relation to the undergraduate population of the respective schools (Table 1). At the end of questionnaire administration, out of the 384 questionnaire copies distributed, 355 copies were successfully collected, collated and deemed suitable for use.

Table 1: Sample size and sampled questionnaire

\begin{tabular}{cccc}
\hline University & Gender & $\begin{array}{c}\text { Undergraduate } \\
\text { Population }\end{array}$ & $\begin{array}{c}\text { Sample } \\
\text { size }\end{array}$ \\
\hline University of Lagos & Male & 15,073 & 84 \\
Sub-total & Female & 10,188 & 57 \\
& & $\mathbf{2 5 , 2 6 1}$ & $\mathbf{1 4 1}$ \\
University of Ibadan & Male & 13,178 & 73 \\
& Female & 8,014 & 45 \\
Sub-total & & $\mathbf{2 1 , 1 9 2}$ & $\mathbf{1 1 8}$ \\
& & & \\
Obafemi & Mwolowo University & 13,292 & 74 \\
& Male & 9,140 & 51 \\
Sub-total & Female & $\mathbf{2 2 , 4 3 2}$ & $\mathbf{1 2 5}$ \\
Grand total & & & $\mathbf{3 8 4}$ \\
\hline
\end{tabular}

\section{Data collection and analysis}

The structured questionnaire was personally administered with assistance of two research assistants. Respondents were not forced to take part in the survey; as such, questionnaire was administered after consent had been given. Data gathered were analysed using tables, simple percentages, bar chart and multiple regression analysis were employed to analyze the quantitative data. In the course of making desirable variables suitable for the application of parametric test, the responses were transformed or recoded into dummies of 1 and 0 (Stockburger, 2012; Valenzuela et al., 2014; Asante and Nyarko, 2014). Hence, responses with positive response (Yes) were recoded as 1 and negative response (No) as 0 and so on. Transformation of the variables 
used initially for descriptive statistics enabled multiple regression analyses to be applied (Stockburger, 2012; Valenzuela et al., 2014).

\section{Result and discussion \\ Demographic characteristics of respondents}

The sex distribution showed that across the three universities, males dominated the survey. The result indicated that $60.3 \%$ of the respondents were males. The result obtained lends support to the finding of Idubor (2015) who reported male undergraduate students' dominance of $71.7 \%$ in social media use and addiction. Similar result was reported by Adebayo (2015) who stated that $56.1 \%$ of the students that used social media sites were males. However, the dominance of males is at variance with the study of Sanghee and Soojung (2014) carried out among college students' in the USA and Korea; the study reported female dominance in the use of social media for health information. The difference may be attributed to differences in culture. Similar reason was ascribed to social media use among Indian women by Narasimhamurthy (2014). This is apparent considering the large number of youths mostly males that usually pursue higher education. In many religion and culture in Nigeria, more parental preference for higher education is normal given to the male child than the female child. The age distribution indicated that in the selected universities, respondents within the ages of 17 19 years dominated the survey, followed closely by those within the ages of 20 - 22years, while those between the ages of <16years had the lowest number. In all, the result shows that majority $(89.0 \%)$ of the respondents in the three universities fall within the ages of 17 -22years; implying that majority of the students surveyed in the three universities are adolescents. This age range is expected because they constitute a good number of undergraduate students. Similar age range or interval was reported by Idubor (2015) where undergraduates aged 16 - 20years were identified to constitute majority of the age cohorts of the study.

The age range of 17 - 22years is expected to have immense influence on social media use as this age group is most obsessed with social media platforms because they can easily adapt to the requirements. This age group spends much of their time daily in utilizing various social media platforms such as Facebook, WhatsApp and Twitter among others. Madden and Smith (2010) opined that users within the ages of 18 - 29years make most use of social networking site. In addition, the religion of respondents identified Christianity and Islam as the widely and commonly practiced religion by $99.4 \%$ of the respondents. It however showed that a good number of the respondents in the three universities were Christians, followed by Islam with traditional worshippers and atheists being unpopular religion. The somewhat increase in the number of Muslim across the universities may be attributed to the geographical location of the study area which has a good number of Muslim faithful or believers. 


\section{Social media and its usefulness in HIV and AIDS information communication}

The result in Table 2 revealed that HIV/AIDS information on social media platforms was very useful. This is so as $90.7 \%$ of the respondents across the universities responded in the affirmative. No doubt, social media sites are vital platforms for the dissemination of information on HIV and AIDS because of its ability to reach millions of users both young and old, as such people are informed on how to prevent being infected and remedies to put in place to improve their situation. In explaining the usefulness of social media in health communication campaign, majority of the respondents across the three universities opined that the platform enables HIV and AIDS information on transmission and prevention reach large audiences. This indeed is the beauty of the new media and its geographic advantage of diffusing information. Another usefulness of social media as opined by the respondents was that access to quality health HIV can be facilitated through the opportunities provided by the social media. This is apparent as the best ways to live with the virus are shared and victims as well as users are made to know how to show care to people leaving with the virus among other quality health information. In a related study, UNAIDS (2011) noted that social media helps to prevent HIV and AIDS by creating awareness through the provision of online resources and information such as the use of condom; need to have an HIV test; discussing HIV testing with one's sexual partner; and knowing about treatment for AIDS victims.

Table 2: Usefulness of social media in HIV and AID information communication

\begin{tabular}{|c|c|c|c|c|c|c|}
\hline \multirow[t]{3}{*}{ Variables } & \multicolumn{6}{|c|}{ Universities } \\
\hline & \multicolumn{2}{|c|}{ OAU } & \multicolumn{2}{|c|}{ Unilag } & \multicolumn{2}{|c|}{ UI } \\
\hline & $\begin{array}{c}\text { Freq } \\
(\mathrm{n}= \\
111)\end{array}$ & $\begin{array}{c}\% \\
(100 \\
)\end{array}$ & $\begin{array}{c}\text { Freq } \\
(\mathrm{n}= \\
130)\end{array}$ & $\begin{array}{c}\% \\
(100 \\
)\end{array}$ & $\begin{array}{l}\text { Freq } \\
(n= \\
114)\end{array}$ & $\begin{array}{c}\% \\
(\mathbf{1 0 0})\end{array}$ \\
\hline \multicolumn{7}{|l|}{ Usefulness of social media } \\
\hline Yes & 95 & 85.6 & 124 & 95.4 & 103 & 90.4 \\
\hline No & 16 & 14.4 & 6 & 4.6 & 11 & 9.6 \\
\hline $\begin{array}{l}\text { If Yes, its usefulness includes } \\
\text { Enable HIV and AIDS information on } \\
\text { transmission and prevention reach } \\
\text { large audiences }\end{array}$ & 65 & 68.4 & 84 & 67.8 & 71 & 68.9 \\
\hline $\begin{array}{l}\text { Access to quality health HIV can be } \\
\text { facilitated through the opportunities } \\
\text { provided by the social media }\end{array}$ & 26 & 27.4 & 34 & 27.4 & 25 & 24.3 \\
\hline $\begin{array}{l}\text { Enables timely, accessible and credible } \\
\text { HIV AND AIDS information }\end{array}$ & 3 & 3.2 & 5 & 4.0 & 6 & 5.8 \\
\hline $\begin{array}{l}\text { It is a trustworthy and credible source } \\
\text { for HIV AND AIDS information }\end{array}$ & 1 & 1.1 & 1 & 0.8 & 1 & 10 \\
\hline
\end{tabular}




\section{Social media awareness and types of HIV and AIDS information shared}

The result in Table 3 provides information on how HIV and AIDS information on social media has helped to inform people about the risks they did not know before. It revealed that the platform had helped informed majority of the respondents about risks they never knew before. This means that HIV and AIDS information shared on social media platforms makes people to be aware of associated risk of the deadly disease such as sharing of sharp objects and unsterilized objects among others. It also increases people's knowledge on how to associate with people living with the virus as well as things than can be shared with victims of the virus. Duggan et al., (2015) stated that the extensive use of social media makes it an essential pathway for communication about HIV and AIDS. However, 36.3\% of the respondents did not feel information shared on social media has in any way added to the knowledge they had before concerning the virus. They stressed that the information they have come across on social media are based on way they have already known, as such no special informed risk practices are attached. The information in Table 3 notwithstanding shows that a significant number learnt new things on HIV and AIDS from the information shared or seen on social media.

On the informed HIV and AIDS risk learnt newly via the social media, a good number of the respondents alleged they learnt new ways of HIV prevention and the several methods to remain negative. This is so as new findings have emerged on ways to successfully prevent contracting the deadly virus and many of these ways are often shared on social media. Another substantial percentage of the respondents learnt more on HIV transmission. Thus with the rising number of young people living with and at risk of HIV (UNAIDS, 2012 cited in Taggart et al., 2015), the social media is vital in exploring the viability of using social media to communicate about HIV prevention and treatment within this age group who are believed to be at risk of infection due to their sexual excesses (Mukhopadhyay et al., 2010). Hence, social media remains an important medium to communicate to young individuals and adults on new methods and ways of HIV/AIDS transmission and prevention. It remains one of the surest avenues to communicate new discoveries on the disease which at present has no known cure as well spread $\mathrm{HIV} / \mathrm{AIDS}$ information. While reporting on the benefits of social media, Okoh (2015) alleged that many people do not know how to protect themselves from the virus as there are still widespread misconception and wrong information about HIV/ AIDS, therefore, social media plays a very important role towards ensuring solving these issues.

Table 3: Social media awareness \& type of HIV and AIDS information shared 


\begin{tabular}{|c|c|c|c|c|c|c|c|}
\hline \multirow[t]{3}{*}{ Variables } & \multicolumn{6}{|c|}{ Universities } & \multirow{3}{*}{$\begin{array}{c}\text { Total } \\
\%\end{array}$} \\
\hline & \multicolumn{2}{|c|}{ OAU } & \multicolumn{2}{|c|}{ Unilag } & \multicolumn{2}{|c|}{ UI } & \\
\hline & $\begin{array}{c}\text { Freq } \\
(n=111)\end{array}$ & $\begin{array}{c}\% \\
(100)\end{array}$ & $\begin{array}{c}\text { Freq } \\
(n= \\
130)\end{array}$ & $\begin{array}{c}\% \\
(100)\end{array}$ & $\begin{array}{c}\text { Freq } \\
(\mathrm{n}= \\
114)\end{array}$ & $\begin{array}{c}\% \% \\
(100 \\
)\end{array}$ & \\
\hline $\begin{array}{l}\text { Knowledge on } \\
\text { HIV/AIDS }\end{array}$ & 71 & 64.0 & 81 & 62.3 & 74 & 64.9 & 63.7 \\
\hline No & 40 & 36.0 & 49 & 37.7 & 40 & 35.1 & 36.3 \\
\hline $\begin{array}{c}\text { Type of HIV/AIDS } \\
\text { information } \\
\text { Not applicable }\end{array}$ & 40 & 36.0 & 49 & 37.7 & 40 & 35.1 & 36.3 \\
\hline $\begin{array}{l}\text { HIV prevention } \\
\text { methods }\end{array}$ & 33 & 29.7 & 50 & 38.5 & 59 & 51.8 & 40.0 \\
\hline HIV transmission & 14 & 12.6 & 25 & 19.2 & 9 & 7.9 & 13.5 \\
\hline $\begin{array}{l}\text { Anti-retroviral } \\
\text { therapy }\end{array}$ & 24 & 21.6 & 6 & 4.6 & 6 & 5.3 & 10.1 \\
\hline
\end{tabular}

\section{Social media sites for HIV and AIDS communication}

Table 4 shows the notably social media sites commonly used by male and female students for HIV and AIDS communication. It also showed that different social media sites were usually used by male and female students to give information on HIV and AIDS. It indicated that blogs $(41.1 \%)$, twitter $(25.4 \%)$ and WhatsApp $(17.7 \%)$ were the social media sites preferred by male and female respondents for sharing HIV and AIDS information, challenges and make necessary enquiries concerning the deadly virus. In a related study carried out among college in the USA and Korea, Sanghee and Soojung (2014) identified blogs, podcast and twitter as the main social media sites used by college students in the two countries for health information. Their study showed that twitter, blogs or podcasts were used because respondents had online relationships with health care professionals, health institutes, health support groups or people with similar health problems. The present study however shows that blog is the widely used social media site for HIV and AIDS communication.

This is expected as there are numerous blogs that provide online health information. For instance, top health life advice (tophealthlifeadvice.com), health in style (healthinstyle.com) and natural medicine box among several others are used as means of creating health awareness for healthy and for people to make informed health decision. These sites give vital information concerning diverse health problems and tips on how to manage them as well as early warning signs or symptoms of many diseases. Apart from these sites, government agencies such as National Agency for the Control of Aids (NACA) in Nigeria has an official twitter and Facebook account where users visit to get up-to-date information on HIV/AIDS and the site shows NACA's activities aimed at eliminating spread of the deadly virus in Nigeria. These social media sites solve geographic barriers and cost of travelling 
some distance to seek for medical advice (Lengyel et al., 2015). This is because users can easily connect with experts online or leave their comments and within some hours, they will get a reply on ways to seek help or solve their health challenge. This is an important component towards the adoption of preventive behaviours among young students in tertiary institutions (Mpofu and Salawu, 2014).

Similarly, Taggart et al., (2015) stated that social media sites make it possible for users to share health information as well as allow users to support one another and share their experiences. Social media site such as blogs, WhatsApp and twitter encourage health group support participation. People with health challenge can feel free to seek medical advice with online experts or doctors as well as share their experiences with group members. Indeed, such platform ignites hope in people with similar health problems and this can be live saving because people will get to know that they are not the only ones having a particular health problem. This agrees with the findings of Mpofu and Salawu (2014) that social networking platforms on HIV and AIDS can become noteworthy pathway for increasing understanding on HIV and AIDS. Indeed, the use of these social media sites for online health enquiries can bring about positive experiences and decisions than negative ones. For example a study carried out by Pew Internet and American Life project cited in Fox and Jones (2009) showed that $60 \%$ of the respondents stated that online health information influenced their decision concerning how to treat or manage an illness, while $56 \%$ stated that online health information changed their approach to maintaining good health.

The result in Table 4 further shows the reasons why male and female respondents preferred the aforementioned social media sites or platforms for HIV and AIDS communication. Similar reasons were upheld by male and female students across the three universities. The result showed that privacy $(47.3 \%)$ was the main reason for the use of these social media sites followed by neutrality $(27.9 \%)$ and then trust $(24.8 \%)$ of the sites. Boyd and Ellison (2007) stated that concerns in relation to privacy have been a decisive problem in using social media sites due to the high risk of unintended publicity of personal information, hacking and identity theft. As such, people use certain sites they believe can ensure privacy in the information shared. Likewise, when people have trust in a particular social media platform, they tend to make use of it more often in sharing confidential messages (Sanghee and Soojung, 2014). Issues on HIV and AIDS are not health challenges that are discussed freely by people in the open due to the fear that grip people when HIV matters are discussed and the high level of stigmatization attached to people with HIV.

As such, people prefer sites with high privacy to be able to discuss HIV issues with online healthcare professionals and institutes. Thus, male and female students using blog, twitter and WhatsApp are encouraged to do so due to the privacy they attach to these sites in 
comparison to others. This process helps to resolve the issues of stigma and cultural factors that hinder free sharing of HIV related information vis-à-vis discussion. Through these platforms, individuals can seek and share information about specific prevention strategies (Taggart et al., 2015) and engage in dialogue about HIV research (Desouza and Jyoti, 2008), and leverage support for issues such as medication adherence and emotional coping for living with HIV (Horvath et al., 2013). Neutrality in participating in online health group is another significant reason for the use of these social media sites. HIV and AIDS information communication is able to offer a neutral platform for engagement people living with the virus to connect and share information on HIV prevention and treatment initiatives (Blackstock et al., 2015). The information shared in Table 3 therefore shows that social media sites with assurance of privacy and trust encourage the use for HIV and AIDS communication with healthcare professionals, health institutions and for people to connect to health support groups or people with similar health problems. Social media is therefore a unique social marketing tool for health communication (Chou et al., 2009; Schein et al., 2010).

Table 4: Social media platforms used for HIV and AIDS communication

\begin{tabular}{|c|c|c|c|c|c|c|c|c|}
\hline \multirow{3}{*}{$\begin{array}{c}\text { Social media } \\
\text { platforms or sites }\end{array}$} & \multicolumn{6}{|c|}{ Universities } & \multirow{3}{*}{$\begin{array}{c}\text { Total } \\
\text { Respo } \\
\text { nse } \\
(355)\end{array}$} & \multirow{3}{*}{$\begin{array}{l}\text { Tot } \\
\text { al } \%\end{array}$} \\
\hline & \multicolumn{2}{|c|}{ OAU } & \multicolumn{2}{|c|}{ Unilag } & \multicolumn{2}{|c|}{ UI } & & \\
\hline & $\begin{array}{c}\begin{array}{c}\text { Freq } \\
(\mathrm{n}= \\
111)\end{array} \\
\end{array}$ & $\begin{array}{c}\% \\
(100 \\
)\end{array}$ & $\begin{array}{c}\begin{array}{c}\text { Freq } \\
(\mathrm{n}= \\
130)\end{array} \\
\end{array}$ & $\begin{array}{c}\% \\
(100 \\
)\end{array}$ & $\begin{array}{c}\text { Freq } \\
(\mathrm{n}= \\
114)\end{array}$ & $\begin{array}{c}\% \\
(100 \\
)\end{array}$ & & \\
\hline BBM & 4 & 3.6 & 5 & 3.8 & 2 & 1.8 & 11 & 3.1 \\
\hline Blogs & 42 & 37.8 & 51 & 39.2 & 53 & 46.5 & 146 & 41.1 \\
\hline Facebook & 10 & 9.0 & 11 & 8.5 & 10 & 8.8 & 31 & 8.7 \\
\hline Google Plus & 5 & 4.5 & - & - & - & - & 5 & 1.4 \\
\hline Instagram & - & - & - & - & - & - & - & - \\
\hline Kinschat & 2 & 1.8 & 4 & 3.1 & - & - & 6 & 1.7 \\
\hline LinkedIn & 3 & 2.7 & - & - & - & - & 3 & 0.8 \\
\hline Skype & - & - & - & - & - & - & - & - \\
\hline Twitter & 18 & 16.2 & 39 & 30.0 & 33 & 28.9 & 90 & 25.4 \\
\hline WhatsApp & 27 & 24.3 & 20 & 15.4 & 16 & 14.0 & 63 & 17.7 \\
\hline YouTube & - & - & - & - & - & - & - & - \\
\hline \multicolumn{9}{|l|}{ Reason (s) for use } \\
\hline Ensures neutrality & 27 & 24.3 & 47 & 36.2 & 25 & 21.9 & 99 & 27.9 \\
\hline Privacy & 46 & 41.4 & 63 & 48.4 & 59 & 51.8 & 168 & 47.3 \\
\hline Trust & 38 & 34.2 & 20 & 15.4 & 30 & 26.3 & 88 & 24.8 \\
\hline
\end{tabular}




\section{Power supply, internet connectivity and social media use}

Social media is a global phenomenon with wide usage and applicability that enables people irrespective of religion, sex and education to connect with one another, become friends and share valuable information. However, the use of this information and communication technology in Nigeria and other African countries is influenced by several environmental factors. The result in Table 5 and Figure 1 revealed that majority $(91.5 \%)$ of the respondents agreed that the use of social media for HIV information communication is affected by the unstable or epileptic nature of power supply in the country. This is so as majority of the students accessed social media sites via their cell phones and personal laptops. The advent of smartphones with wireless application has led to the decline in the use of Cyber cafes (Olofinlua, 2015). The response is also true as the country cannot boost of 24 hours steady supply of power (Omotosho et al., 2015) and in many cities and villages, power is not supplied for weeks. This significantly affects the use of social media due to the problem of charging the phones (Smartphone).

Though the universities have generating plants, but the generation of power is still unstable. Since, the universities cannot rely on power supply to meet up their daily demands for energy supply, Chinese solar power and chargers are used to complement power supply. The supply of power from this source is however, restricted to some offices. The persistent problem of unstable power supply has made many Nigerians to buy power-bank of different storage capacities with the intention to charge phones when they drain. This power-banks need power/electricity for them to be charged, as such, in the absence of electricity supply for days and weeks, many phones are shutdown and this affect people's use of social media. This affects users' ability to connect frequently to online HIV discussion forum.

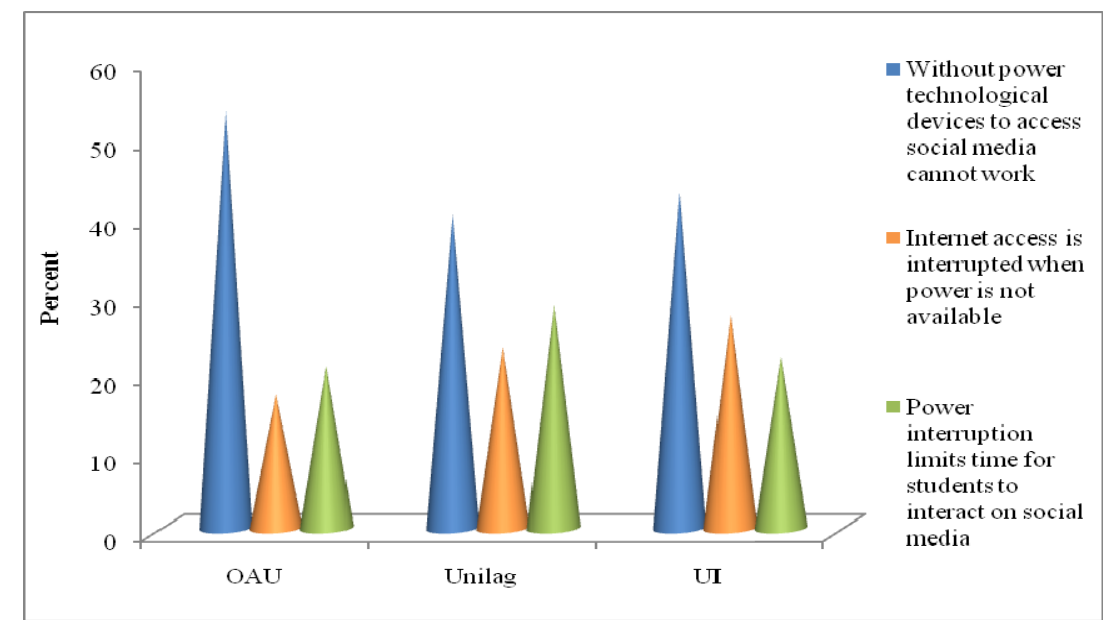

Figure 1: Effect of unstable power supply on social media use 
On the effect of unstable power supply on social media use, the result showed that inability of the technological devices to access social media and limitation of the time students interact on social media are the two problems of interrupted and unstable power supply. Apparently, devices (laptops, Smart-phones, desktops, etc) usually used to access social media sites depend on electricity for power, in the absence of electricity, they cannot function properly. Also, many students have time they log onto the sites to connect with their friends and loved ones, and if this elapses they may not be able to connect with them due to individuals' busy nature and engagements to make ends meet. For students, they have time they are free to chat with their loved ones and so on.

Network connectivity was affirmed by $82.3 \%$ to another serious barrier to the effective use of social media for health information communication (Table 5 and Figure 2). When network is poor, connectivity to several social media sites is restricted and if connected, the user would not be able to chat effectively. Messages and pictures cannot be shared or sent and uploaded successfully with poor network. This indeed is one of the major challenges of continuous use of social media. This has made many students who have the financial capacity to subscribe to more than one network to enable them swap network if one of the network experiences problem.

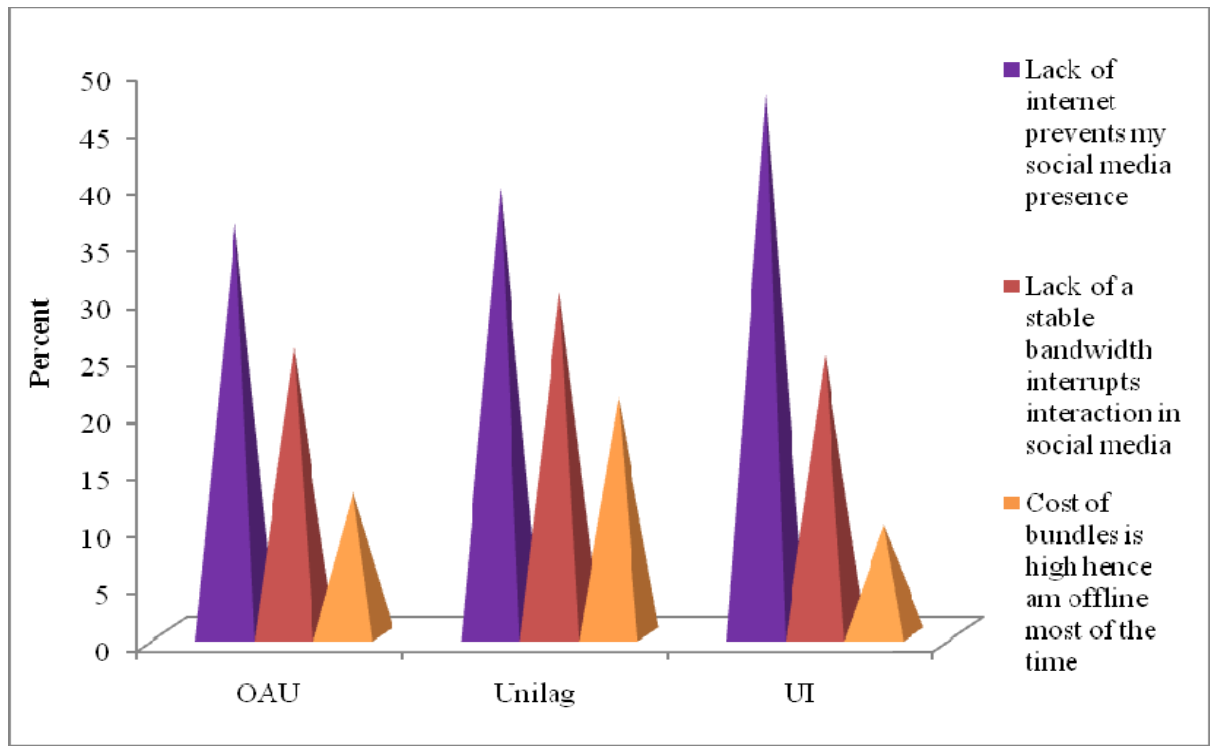

Figure 2: Effect of network connectivity on social media use

On the other hand, students who are not able to follow same approach are constrained to access the internet and make use of social media. This agrees with the result of Abdelraheem and Ahmed (2015) who found lack of high-speed internet (poor network connectivity) as the paramount barrier that affects electronic social media usages. In addition, the result identified prevention of users' presence and interruption of interaction by unstable bandwidth as the effects of poor 
network connectivity on the social media use. Alison et al., (2012) cited in Emwanta and Nwalo (2015) found literacy, low bandwidth and limited number as factors affecting the utilization of e-resources resources.

Table 5: Respondents' assessment of power supply and cost of subscription on of social media use

\begin{tabular}{|c|c|c|c|c|c|c|}
\hline \multirow[t]{3}{*}{ Variables } & \multicolumn{6}{|c|}{ Universities } \\
\hline & \multicolumn{2}{|c|}{ OAU } & \multicolumn{2}{|c|}{ Unilag } & \multicolumn{2}{|c|}{ UI } \\
\hline & $\begin{array}{c}\text { Freq } \\
(\mathrm{n}= \\
111)\end{array}$ & $\begin{array}{c}\% \\
(100)\end{array}$ & $\begin{array}{c}\text { Freq } \\
(\mathrm{n}= \\
130)\end{array}$ & $\begin{array}{l}\% \\
(10 \\
0)\end{array}$ & $\begin{array}{c}\text { Freq } \\
(\mathrm{n}= \\
114)\end{array}$ & $\begin{array}{c}\% \\
(100)\end{array}$ \\
\hline \multicolumn{7}{|l|}{ Influence of power supply } \\
\hline Yes & 101 & 91.0 & 119 & $\begin{array}{c}91 . \\
5\end{array}$ & 105 & 92.1 \\
\hline No & 10 & 9.0 & 11 & 8.5 & 9 & 7.9 \\
\hline \multicolumn{7}{|l|}{ If Yes, effects of power supply } \\
\hline $\begin{array}{c}\text { Without power technological } \\
\text { devices to access social media } \\
\text { cannot work }\end{array}$ & 59 & 58.4 & 52 & $\begin{array}{c}43 . \\
7\end{array}$ & 49 & 46.7 \\
\hline $\begin{array}{l}\text { Internet access is interrupted } \\
\text { when power is not available }\end{array}$ & 19 & 18.8 & 30 & $\begin{array}{c}25 . \\
2\end{array}$ & 31 & 29.5 \\
\hline $\begin{array}{l}\text { Power interruption limits time } \\
\text { for students to interact on social } \\
\text { media }\end{array}$ & 23 & 22.8 & 37 & $\begin{array}{c}31 . \\
1\end{array}$ & 25 & 23.8 \\
\hline $\begin{array}{c}\text { Influence of network } \\
\text { connectivity } \\
\text { Yes }\end{array}$ & 82 & 73.9 & 117 & $\begin{array}{c}90 . \\
0\end{array}$ & 93 & 81.6 \\
\hline No & 29 & 26.1 & 13 & $\begin{array}{c}10 . \\
0\end{array}$ & 21 & 18.4 \\
\hline $\begin{array}{c}\text { If Yes, effect } \\
\text { Lack of internet prevents my } \\
\text { social media presence }\end{array}$ & 40 & 48.8 & 51 & $\begin{array}{c}43 . \\
6\end{array}$ & 54 & 58.1 \\
\hline $\begin{array}{l}\text { Lack of a stable bandwidth } \\
\text { interrupts interaction in social } \\
\text { media }\end{array}$ & 28 & 34.1 & 39 & $\begin{array}{c}33 . \\
3\end{array}$ & 28 & 30.1 \\
\hline $\begin{array}{l}\text { Cost of bundles is high hence am } \\
\text { offline most of the time }\end{array}$ & 14 & 17.1 & 27 & $\begin{array}{c}23 . \\
1\end{array}$ & 11 & 11.8 \\
\hline
\end{tabular}

Assessment of ICT skills and cost of subscription on social media use

Other factors that affect the successful use of social media sites for HIV/AIDS information communication included ICT skills and cost of subscription (Table 6). In the context of the present study, little ICT skill may be required to access and make use of Facebook and WhatsApp. Emwanta and Nwalo (2015) stated that computer literacy has substantial influence on students' use of electronic information resources. These social media sites can be used or accessed by any student because they are not rocket-sciences. However, cost of subscription remains a big challenge to social media use among the students. In the three selected universities for the present study, the cost of accessing the internet is borne by the students who make use of their cell phones and personal 
laptops to make use of social media sites. Indeed, without any workable data, access to the internet is completely denied and messages as well as pictures cannot be sent and uploaded successfully. In a similar study, Ajayi (2015) identified cost of internet subscription (cost of access data) as one of the factors that affect the use of social media sites. In concise, the efficient and effective use of social media sites are influenced by unstable power supply, ICT skills, cost of subscription and network problem. The result obtained corroborates the study of Emwanta and Nwalo (2015) that the use of social media sites is affected by unstable power supply, lack of essential computer skills and unavailability and inaccessibility of electronic resources.

Table 6: Assessment of ICT skills and cost of subscription on social media use

\begin{tabular}{|c|c|c|c|c|c|c|}
\hline \multirow[t]{3}{*}{ Variables } & \multicolumn{6}{|c|}{ Universities } \\
\hline & \multicolumn{2}{|c|}{ OAU } & \multicolumn{2}{|c|}{ Unilag } & \multicolumn{2}{|c|}{ UI } \\
\hline & $\begin{array}{c}\text { Freq } \\
(\mathrm{n}= \\
\mathbf{1 1 1})\end{array}$ & $\begin{array}{c}\% \\
(\mathbf{1 0} \\
\mathbf{0})\end{array}$ & $\begin{array}{c}\text { Freq } \\
(\mathrm{n}= \\
130)\end{array}$ & $\begin{array}{c}\% \\
(\mathbf{1 0} \\
0)\end{array}$ & $\begin{array}{c}\begin{array}{c}\text { Freq } \\
(\mathrm{n}= \\
114)\end{array}\end{array}$ & $\begin{array}{c}\% \\
(100 \\
)\end{array}$ \\
\hline $\begin{array}{c}\text { ICT skills affect usage } \\
\text { Yes }\end{array}$ & 79 & 71.2 & 84 & 64.6 & 81 & 71.1 \\
\hline No & 32 & 28.8 & 46 & 35.4 & 33 & 28.9 \\
\hline $\begin{array}{c}\text { Subscription cost affects usage } \\
\text { Yes }\end{array}$ & 98 & 88.3 & 124 & 95.4 & 107 & 93.9 \\
\hline No & 13 & 11.7 & 6 & 4.6 & 7 & 6.1 \\
\hline
\end{tabular}

\section{Availability of technological and social media usage}

The use of social media platforms is made possible by the existence and availability of technological facilities that facilitate its usage. These facilities are presented in Table 7. It showed that the availability of advanced technological devices was noted by a larger percentage of the respondents to facilitate the use of social media. This is glaring as the presence and easy access of these devices make it easy to access social media. One of such advanced technological devices is Smart-phones and I-phones among other sophisticated Window phones and laptops that enable the installation and use of social media platforms. Many of the social media applications such as BBM, Instagram and LinkedIn among others can effectively run on devices with OS (operating systems) of 4.0 and above. Phones and devices with lesser capacity of OS and RAM sizes affect the smooth or seamless operation of these social media platforms or sites. Thus, the availability of these devices, though at exorbitant rates make it possible for students to use social media for numerous purposes. Another factor that determines the use of social media is the friendly nature or ease of use of social media platforms. This is apparent as many of the social media applications are user friendly and users do not require any special skill or training to make use of them. For instance, sites like Facebook and 
WhatsApp among others have users' friendly interface that makes it easy for any students to operate. However, cost of purchase (such as buying cost) is alleged by $7 \%$ of the students (respondents) to affect the use of social media. This category of students believes this factor contributes to making social media less accessible. The result in Table 7 therefore shows that availability of advanced technological devices and friendly nature or ease of use of social media platforms determines usage of social media sites.

Table 7: Effect of technological facilities on social media usage

\begin{tabular}{|c|c|c|c|c|c|c|}
\hline \multirow[t]{3}{*}{ Options } & \multicolumn{6}{|c|}{ Universities } \\
\hline & \multicolumn{2}{|c|}{ OAU } & \multicolumn{2}{|c|}{ Unilag } & \multicolumn{2}{|c|}{ UI } \\
\hline & $\begin{array}{l}\text { Freq } \\
(\mathrm{n}= \\
111)\end{array}$ & $\begin{array}{l}\% \\
(10 \\
0)\end{array}$ & $\begin{array}{c}\text { Freq } \\
(\mathrm{n}= \\
130)\end{array}$ & $\begin{array}{l}\% \\
(10 \\
0)\end{array}$ & $\begin{array}{l}\text { Freq } \\
(\mathrm{n}= \\
114)\end{array}$ & $\begin{array}{c}\% \\
(100 \\
)\end{array}$ \\
\hline $\begin{array}{l}\text { Advanced technological devices } \\
\text { make it easy to access social media }\end{array}$ & 57 & 51.4 & 77 & 59.2 & 50 & 43.9 \\
\hline $\begin{array}{l}\text { The applications of social media } \\
\text { platforms are user friendly }\end{array}$ & 44 & 39.6 & 34 & 26.2 & 53 & 46.5 \\
\hline $\begin{array}{l}\text { Cost of technological devices has } \\
\text { reduced making social media more } \\
\text { accessible }\end{array}$ & 6 & 5.4 & 10 & 7.7 & 9 & 7.9 \\
\hline $\begin{array}{l}\text { Social media applications are free } \\
\text { hence readily available }\end{array}$ & 4 & 3.6 & 9 & 6.9 & 2 & 1.8 \\
\hline
\end{tabular}

Influence of power supply, internet connectivity, ICT skills and subscription cost on social media use

Here, stepwise multiple regression analysis was performed to examine the relative influence of power supply, internet connectivity, ICT skills and subscription cost on social media use for HIV communication. The essence of this analysis was to identify the main factor that influences the use of social media. According to Attua (2009) stepwise multiple regression analysis is valuable when finding the best subset of predictors. Before the analysis was carried out, the respective items chosen were transformed into dummies of 1 and 0 . The result obtained is shown in Table 8. ICT skill was retained as the only variable that influenced the use of social media. It revealed that ICT skill was responsible for $33.9 \%$ of the variation in social media use for HIV communication. The ANOVA result indicated that ICT skill had a significant influence on social media use for HIV communication ( $\mathrm{F}=$ $4.234, \mathrm{p}<0.05)$. This result agrees with the finding of Emwanta and Nwalo (2015) when they identified ICT skill as one of the potent factors that influence students' use of electronic information resources such as Facebook, WhatsApp and Twitter among others. 
The sign of the regression coefficient indicated a positive relation implying increase in social media use with the increase in ICT skills. The standardized regression result showed that a unit increase in ICT skill will bring about $10.9 \%$ of the increase in social media use for HIV communication (Table 8). The result implies that ICT skill can significantly impact on social media use for HIV communication. This is glaring as the more students acquire ICT skills, the more their use of social media sites for HIV communication. This is so as they will be able to engage with health care experts on diverse social media sites, as well as be able to navigate or access various health-related sites to build online acquaintance with other people with similar health problems. In order to make effective use of social media, necessary ICT skills (mode of operation and ways to access and connect to with people on similar health problems) is required for maximum output. ICT skills provide opportunities for students and individuals to engage outside classroom setting and making it possible for them to easily interact, learning and share HIV related information (Rizal and Steven, 2012).

Thus, the ability to make effective use of social media sites for HIV communication beyond just chatting makes students to enjoy the platforms and this can increase use and privacy to discuss HIV issues. Many students and young individuals as well as adult who find it difficult to use and navigate between social media platforms is because of their poor ICT skills. It also enables users to be careful of suspicious and unnecessary sites and add-on that can affect easy use of social media for HIV communication. Having requisite ICT skills mostly on ways to adequately make use of social media sites enables youths living with HIV to communicate with a diverse range of users across various geographic and social contexts where anonymity and confidentiality in communication concerning HIV prevention and treatment is assured (Taggart et al., 2015). Such site enables youths infected to freely discuss their experience and treatment challenges as well as share side effects of using certain drugs. The sharing of such information enables better medication to be suggested and prescribed by experts who are part of the online discussion forum.

Table 8: Summary of stepwise multiple regression result

\begin{tabular}{cccc}
\hline Predictor variable & \multicolumn{3}{c}{ Coefficients } \\
\cline { 2 - 4 } & B & B & t-value \\
\hline ICT skills & 0.106 & 0.109 & \\
& & & \\
Test results & & & \\
F- value & $4.234^{*}$ & \\
$\mathrm{R}$ & 0.583 & & $14.939^{*}$ \\
$\mathrm{R}^{2}$ & 0.339 & & \\
Constant & 0.640 & & \\
Std Error & 0.451 &
\end{tabular}

*Significant at 0.05 significance level 


\section{Conclusion}

The study has shown that use of social media by undergraduates for HIV information communication in the three universities is seriously affected by epileptic nature of power supply, poor network connectivity, ICT skills and cost of subscription. These setbacks have substantial impact on the use of social media for HIV information communication. The time of use, efficient use and willingness to make use of the various social media sites to connect with people with similar health problems as well as get professional advice from experts on same online discussion forum are hampered by these environmental factors. Nevertheless, among these barriers of social media use, ICT skill was identified as the principal factor that influence social media use for HIV information communication. This is apparent because if others are available, efficient use of social media sites for health communication can be hampered by undergraduates' inability to handle advanced technological devices and their different applications. Having adequate knowledge on the use of social media sites and knowledge or techniques to search for online HIV discussion forum enables youths mostly those living with the deadly virus to get help on ways to manage the epidemic as well as ways to properly deal with the side effects of their current medications. The study however suggested creation of campaign on prominent HIV and AIDS discussion sites and ICT skill acquisition to enable youth connect and effectively make use of social media for HIV information communication.

\section{References}

Abdelraheem, A. Y. and Ahmed, A. M. (2015)

Electronic social media in teaching: usages, benefits, and barriers as viewed by Sudanese faculty members. American International Journal of Social Science, 4 (5): 58 - 68.

Ajayi, J. O. (2015).

Use and use intensity of social media networking systems by

Nigerian agro-entrepreneurs. Scientific Papers Series Management, Economic Engineering in Agriculture and Rural Development, 15 $(1): 19-26$.

Asante, K. O. and Nyarko, J. (2014).

The physical and behavioural consequences of Facebook use among university students. Mediterranean Journal of Social Sciences, 5 (27): $774-781$.

Attua, E. M. (2009).

Using multiple linear regression techniques to quantify carbon stocks of fallow vegetation in the tropics. West African Journal of Applied Ecology, 12: 1 - 7 
Blackstock, O. J., Haughton, L. J., Garner, R. Y., Horvath, K. J., Norwood, C., and Cunningham C. O. (2015).

General and health-related Internet use among an urban, community-based sample of HIV-positive women: implications for intervention development. AIDS Care, 27 (4): 536-44.

Blackstock, O. J., Haughton, L. J., Garner, R. Y., Horvath, K. J., Norwood, C., and Cunningham, C. O. (2015).

General and health-related Internet use among an urban, community-based sample of HIV-positive women: implications for intervention development. AIDS Care, 27 (4): 536-44.

Chou, S. C., Hunt, Y. M., Beckjord, E. B., Moser, R. P. and Hesse, B. W. (2009).

Social Media Use in the United States: Implications for Health Communication. Journal of Medical Internet Research, 11(4): e48.

Desouza, R. and Jyoti, D.M. (2008).

Global and local networking for HIV/ AIDS prevention: the case of the Saathii E-forum. Journal of Health Communication, 13(4):32644.

Desouza, R. and Jyoti, D.M. (2008).

Global and local networking for HIV/ AIDS prevention: the case of the Saathii E-forum. J Health Commun. 13(4):326-44.

Emwanta, M. and Nwalo, K. I. N. (2015).

Influence of computer literacy and subject background on use of electronic resources by undergraduate students in universities in South-western Nigeria. International Journal of Library and Information Science, 5(2): 29 - 42.

Ephraim, P. E. (2013).

African youths and the dangers of social networking: a culturecentered approach to using social media. Ethics and information technology, 15(4), 275-284.

Fox, S. and Jones, S. (2009).

The social life of health information: Americans' pursuit of health takes place within a widening network of both online and offline sources. Pew Internet and American Life Project. Retrieved from http://www.pewinternet.org/ /media//Files/Reports/2009/PI P_Health_2009.pdf.

Horvath, K. J., Oakes, J. M., Rosser, B. R., Danilenko, G., Vezina, H., Amico, K. R., Williams, M. L. and Simoni, J. (2013).

Feasibility, acceptability and preliminary efficacy of an online peer-to-peer social support ART adherence intervention. AIDS Behaviour. 17(6): 2031-44.

Horvath, K. J., Oakes, J. M., Rosser, B. R., Danilenko, G., Vezina, H., Amico, K. R.Williams, M. L. and Simoni, J. (2013). Feasibility, acceptability and preliminary efficacy of an online peer-to-peer social support ART adherence intervention. AIDS Behav. 17(6): 2031-44. 
Hughes, D., Rowe, M., Batey, M., and Lee, A. (2012).

A tale of two sites: Twitter vs Facebook and the personality predictors of social media usage. Computers in Human Behavior, 28(2):561-569.

Idowu, A. P., Idowu, A. O. and Adagunodo, E. (2004).

A comparative study of information and communication technologies at higher educational institutions in Africa: Case Studies from Nigeria \& Mozambique. Journal of Information Technology Impact, 4 (2): 67-74

Idubor, I. (2015).

Investigating social media usage and addiction levels among undergraduates in University of Ibadan, Nigeria. British Journal of Education, Society E Behavioural Science, 7(4): 291-301.

Kaplan, A. M. and Haenlein, M. (2010) Users of the world, unite! The challenges and opportunities of social media. Business Horizons, 53(1): 59-68.

Lengyel, B., Varga, A., Sagvari, B., Jakobi, A. and Kertesz, J. (2015) Geographies of an online social network. PLoS ONE, 10(9): e0137248

Madden, M. and Smith, A. (2010) Reputation management and social media. Pew Internet $\mathcal{E}$ American Life Project, 2. Retrieved from http://www.pewinternet.org/ /media//Files/Reports/2010/PI P_Reputation_Management_with_topline.pdf. May 17, 2016

Madden, M., Lenhart, A., Cortesi, S., Gasser, U., Duggan, M., Smith, A., \& Beaton, M. (2013). Teens, social media, and privacy. Pew Research Center, 21, 2-86. Retrieved from:

http:// www.pewinternet.org/2013/05/21/teens-social-mediaand-privacy/ on June 12, 2016

Markwei, E. D. and Appiah, D. (2016).

The impact of social media on Ghanaian Youth: a case study of the Nima and Maamobi communities in Accra, Ghana. The Journal of Research on Libraries and Young Adults, 7 (2): 1 - 26.

Mingle, J. and Adams, M. (2015).

Social media network participation and academic performance in senior high schools in Ghana. Library Philosophy and Practice (ejournal). Paper 1286.

http:/ / digitalcommons.unl.edu/libphilprac/1286

Mpofu, N. and Salawu, A. (2014).

Contributions of HIV AND AIDS social networking sites towards awareness and prevention of the pandemic among students of Rhodes University, South Africa. Mediterranean Journal of Social Sciences, 5 (6): 191 - 202.

Narasimhamurthy, N. (2014). Cultural impact and gender on Indian young adults in using social networking sites. International Journal of Interdisciplinary and Multidisciplinary Studies, 1 (7):113 - 125. 
Odine, M. (2015).

Effective communication for HIV/AIDS in Africa. The

International Journal of Communication and Health, 5: 1 - 8 .

Olofinlua, O. (2015).

How mobile internet killed off cyber cafés in Nigeria. Retrieved

from: https:/ / qz.com/412745/how-mobile-internet-killed-off-

cyber-cafes-in-nigeria/

Olowu, A. O. and Fasola, O. S. (2012).

A study of social network addiction among youths in Nigeria. Journal of Social Science and Policy Review, 4: 62-71.

Omotosho, A. O., Lateef, E. B., Amusa, O. I. and Bello, T. O. (2015).

Information and communication technology adoption and use among students of a Nigerian University for distance learning. Library Philosophy and Practice (e-journal).Paper

1246.http:/ / digitalcommons.unl.edu/libphilprac/1246

Sago, B. (2013).

Factors influencing social media adoption and frequency of use: an examination of Facebook, Twitter, Pinterest and Google ${ }^{+}$. International Journal of Business and Commerce, 3 (1): 01-14.

Sanghee, O. and Soojung, K. (2014).

College students' use of social media for health in the USA and Korea. Retrieved from: http://www.informationr.net/ir/194/paper643.html

Schein, R., Wilson, K. And Keelan, J. (2010).

Literature review on effectiveness of use of social media. $A$ report for Peel public health. Brampton, ON: Peel Public Health.

Stockburger, D. W. (2012).

Multiple regression with categorical variables. Retrieved from:

http:/ / www.psychstat.missouristate.edu/multibook/mlt08m.ht $\underline{\mathrm{ml}}$. on June 15, 2017

Taggart, T., Grewe, M E., Conserve, D. F, Gliwa, C. and Isler, M. R. (2015) Social media and HIV: a systematic review of uses of social media in HIV communication. J. Med Internet Res., 17 (11): 2248

Valenzuela, S., Arriagada, A., And Scherman, A. (2014).

Facebook, Twitter, and youth engagement: a quasi-experimental study of social media use and protest behavior using propensity score matching. International Journal of Communication, 8, 20462070.

\section{Acknowledgement}

This research was supported by the Consortium for Advanced Research Training in Africa (CARTA) a body that is jointly led by the African Population and Health 
Research Center and the University of the Witwatersrand and funded by the Wellcome Trust (UK) (Grant No: 087547/Z/08/Z), the Department for International Development (DfID) under the Development Partnerships in Higher Education (DelPHE), the Carnegie Corporation of New York (Grant No: B 8606), the Ford Foundation (Grant No: 1100-0399), Google.Org (Grant No: 191994), Sida (Grant No: 54100029) and MacArthur Foundation Grant No: 10-95915-000-INP. 